\title{
Effectiveness of Portfolio Selection Using Markowitz Model and Broker Recommendation in Indonesia Stock Exchange (Mining, Agriculture, and Infrastructure Industry)
}

\section{Vindaniar Y. Putri}

Vocational Program, Universitas Indonesia, Depok, Indonesia

\section{Abstract}

This article analyzes the effectiveness of Portfolio Selection Using Markowitz Model and brokerage recommendation in Indonesia Stock Exchange (Mining, Agriculture, and Infrastructure Industry) in 2016. This study aims at determining the more effective

Corresponding Author: Vindaniar Y. Putri vinda24@gmail.com

Received: 8 June 2018 Accepted: 17 July 2018 Published: 8 August 2018

Publishing services provided by Knowledge $\mathrm{E}$

(c) Vindaniar Y. Putri. This article is distributed under the terms of the Creative Commons

Attribution License, which permits unrestricted use and redistribution provided that the original author and source are credited.

Selection and Peer-review under the responsibility of the 2 nd ICVHE Conference Committee. model between Markowitz Model and brokerage recommendation for minimizing the risk and maximizing the expected return in investor's portfolio. The study has used quantitative and qualitative approach. The research model used was Markowitz Model to divide and determine the proportion of the stock quantitatively. On the other hand, brokerage recommendations were also used to determine the stocks qualitatively as comparative to the Markowitz Model. Thereafter, the stocks from Markowitz Model and brokerage recommendation were observed for three months on weekly basis to calculate the stock and portfolio returns. Moreover, OLS regression was performed to analyze the effectiveness of Markowitz Model and brokerage recommendation. The result of this article indicated that Markowitz Model was more effective to be used as portfolio-selection tool than the broker recommendation.

Keywords: Markowitz Model, brokerage, portfolio selection, OLS regression, stock market

\section{Introduction}

There are many kinds of securities in capital market nowadays internationally or locally may cause the expansion of asset securities for investor. This condition makes investor have risk and the rate of return at the same rate or even risk smaller than the rate of return. Moreover, the good investor will able to diversify their assets among industries/sectors, which will produce lower risk and higher expected return for their portfolio. The possibility to reach risk-return-trade-off in some kind of securities supported 
by annual return and standard deviation from each shares will producing optimal return overall.

Generally, portfolio investment is the diversification in some investment instrument done by individual investors or institution. The purpose of investors to form portfolio by any investment instrument was only to reduce the risk. Diversification is very important to be done because the most of investors still avoiding the risk. The more numerous investment instruments are chosen, then the more risk can be minimized.

Focus of this article is on the investment shares that can be trade through stock exchange. Hence, there are several modifications from Robert Ang's theory of developing investment portfolio.

\section{Literature Review}

\subsection{Portfolio}

When managing assets, investors have to select and combined in certain composition and proportion so that it can be reach the optimum point between risks and required return. The asset combination in unity is called portfolio investment (Bayumashudi, 2006). Moreover, Frank J. Fabozzi (1999) stated that portfolio theory is associated with portfolio selection, which can maximize the investment return according to the risk that can be accepted. Through a quantitative model and historical data, this theory is able to count the rate of expected portfolio return and the acceptable risk of a portfolio, also shows how to form an optimal portfolio (Nuraida, 2004).

A portfolio also has rate of return and rate of risk similar as other investment assets. However, forming a portfolio is an effort to make the best trade-off between risk and return. Low risk doesn't mean will satisfy the investor because it tends to generate low return. In reverse, high return usually correlated with high rate of return. Rational investor will looking for the best combination between risk and return for its portfolio (Bayumashudi, 2006).

\subsection{Markowitz portfolio model}

Harry Markowitz introduced portfolio theory for the first time. Together with his friend, William Sharpe, the founder of capital market theory he got a noble in October 1990. Quantitatively, Markowitz shows how diversified portfolio able to minimize risk. Portfolio risk is not only about weighted average from every stocks/assets in portfolio, but 
also considered the correlation between stocks. Statistic concept such as coefficient correlation and covariance in this case is very important.

Markowitz approach in developing portfolio is that investors must evaluate their portfolio based on their expected return and the risk, which measured by standard deviations. Markowitz then publishing the concept called efficient portfolio. Efficient portfolio is portfolio, which had the smallest risk for the same expected return, or the largest expected return for the same risk.

\section{Methodology}

This study uses a quantitative approach. As for data was carried out in two ways, namely literature study and field study. Literature study conducted by books and other scientific papers and journals that can support the research. Field study conducted by collecting the secondary data that will be used for data process. This study is using weekly data with period of during September 2014 until September 2016. All the data are in Indonesia Rupiah and are from Datastream database.

\subsection{Research model}

Shares to put into portfolio should be having negative correlation to each other. Therefore, first of all we have to calculate the correlation between sectors in Indonesia stock exchange (IDX). IDX divided their company's member into 10 sectors, such as agricultural, mining, basic industry, miscellaneous, consumer goods, property and real estate, infrastructure, finance, trade and service, and manufacturing sectors. After we make the correlation calculation through Microsoft excel, obtained data that has negative correlation is sector:

TABLE 1: Negative correlation among industries in Indonesia Stock Exchange (IDX).

Industries
Agriculture - consumer good
Agriculture - Property
Agriculture - Infrastructure
Mining - Consumer goods
Mining - Trade
Misc. - Consumer goods

\section{Coefficient Correlation}

$-0.271421004$

$-0.037056805$

$-0.170266747$

$-0.643719949$

$-0.030515168$

$-0.228777374$ 
From Table 1, we can select several companies from every industry who has negative correlation such as agriculture, mining, and infrastructure industry. The selected company is the company in board 1 position or blue chip stocks, big market capitalization in every, high trading value, and based on broker recommendation. Broker recommendations are based on equity analyst report from July 2016 to September 2016. The details are as follows:

TABLE 2: Market capitalizations and trading value from agriculture, mining, and infrastructure industry.

\begin{tabular}{|c|c|c|c|}
\hline COMPANY & CODE & TV (in Bio Rp) & $\begin{array}{c}\text { MARKET CAPT (in } \\
\text { Bio Rp) }\end{array}$ \\
\hline Adaro Energy, Tbk & ADRO & 9.198 & 16.473 \\
\hline Bayan Resources, Tbk & BYAN & 18 & 26.250 \\
\hline Vale Indonesia, Tbk & INCO & 6.858 & 16.246 \\
\hline $\begin{array}{l}\text { Aneka Tambang (Persero), } \\
\text { Tbk }\end{array}$ & ANTM & $5 \cdot 387$ & 7.546 \\
\hline $\begin{array}{l}\text { Tambang Batubara Bukit } \\
\text { Asam (Persero), Tbk }\end{array}$ & PTBA & 7.109 & 10.426 \\
\hline Astra Agro Lestari, Tbk & AALI & 7.681 & 24.960 \\
\hline $\begin{array}{l}\text { PP London Sumatra } \\
\text { Indonesia, Tbk }\end{array}$ & LSIP & 8.970 & 9.006 \\
\hline SMART, Tbk & SMAR & 3 & 12.063 \\
\hline Jasa Marga (Persero), Tbk & JSMR & 2.446 & 35.530 \\
\hline $\begin{array}{l}\text { Perusahaan Gas Negara, } \\
\text { Tbk }\end{array}$ & PGAS & 36.449 & 66.543 \\
\hline $\begin{array}{l}\text { Tower Bersama } \\
\text { Infrastructure, Tbk }\end{array}$ & TBIG & 9.753 & 28.180 \\
\hline $\begin{array}{l}\text { Sarana Menara Nusantara, } \\
\text { Tbk }\end{array}$ & TOWR & 967 & 48.464 \\
\hline $\begin{array}{l}\text { Telekomunikasi Indonesia } \\
\text { (Persero), Tbk }\end{array}$ & TLKM & 67.354 & 312.984 \\
\hline Delta Dunia Makmur, Tbk & DOID & 401 & 447 \\
\hline
\end{tabular}

From Table 2, it can be seen that shares of the selected stocks is on the Indonesia Stock Exchange main board, which means these stocks are shares from the first liner. Shares from the first liner are having the characteristics of high trading value. Trading value obtained based on the calculation of stock trading at a particular period multiplied by the price of the stock at the time. Shares of the first liner are also having the great number of market capitalization. It can be seen from Table 2, too. 
Before we determine weights to each stock then first calculate the global minimum variance portfolio (a limit rational investors) and optimal risky portfolio (critical interface between best possible capital allocation line (CAL) and efficient frontier) by Markowitz. The following is illustration of global minimum variance portfolio and optimal risky portfolio):

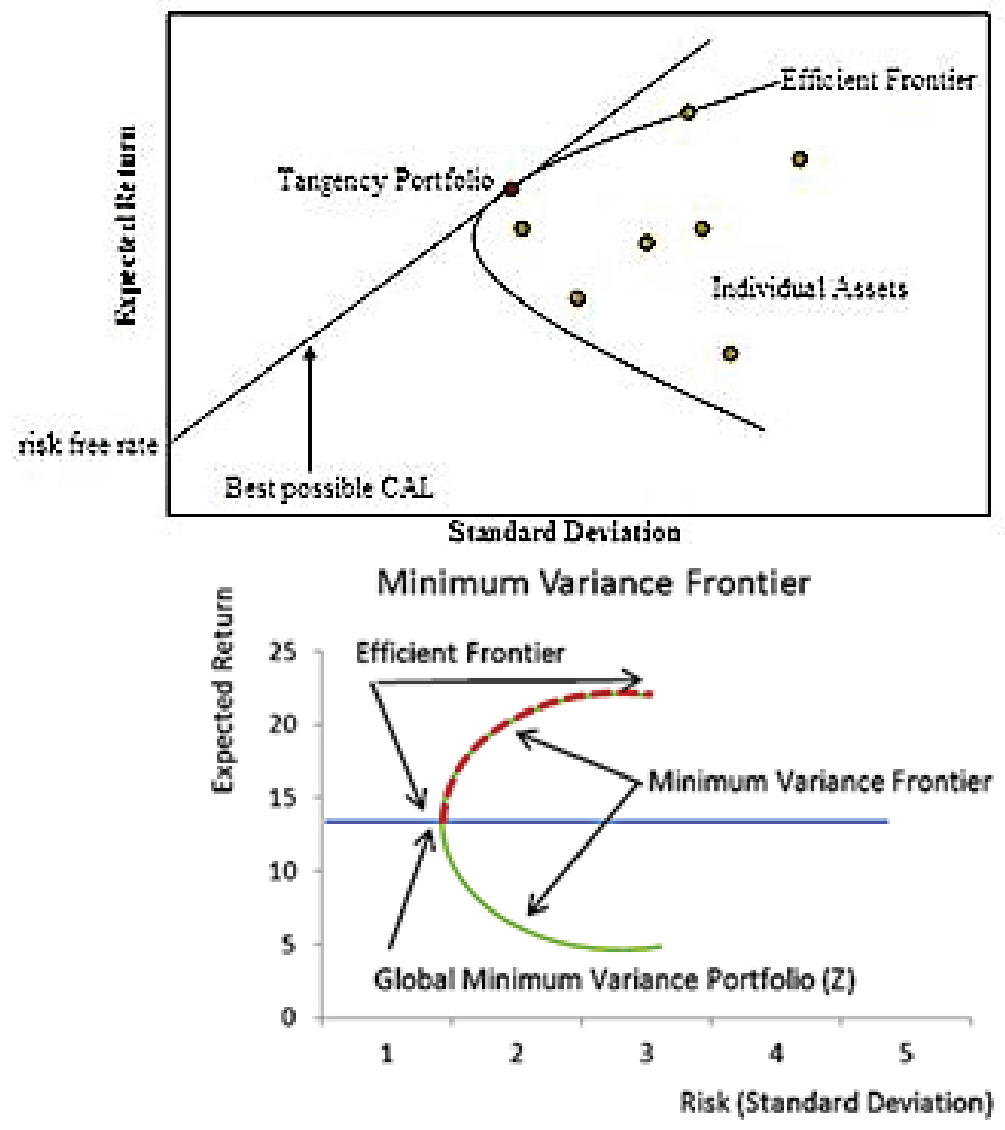

Figure 1: Variance Frontier and Efficient Frontier.

The purpose of this research is to compare between Markowitz portfolio model's performance and broker recommendation's performance. Thus, there are two unit observations in this research. The first one is based on Markowitz portfolio model the second one is based on broker recommendation. Shares selections for Markowitz portfolio are based on trading value and market capitalization as mentioned earlier. On the other hand, equity analyst reports from Trimegah Securities, Tbk are used as proxy for broker recommendation. 
TABLE 3: Markowitz portfolio.

\begin{tabular}{l|l}
\hline COMPANY & CODE \\
\hline Adaro Energy, Tbk & ADRO \\
\hline Bayan Resources, Tbk & BYAN \\
\hline Vale Indonesia, Tbk & INCO \\
\hline Aneka Tambang (Persero), Tbk & ANTM \\
\hline $\begin{array}{l}\text { Tambang Batubara Bukit Asam } \\
\text { (Persero), Tbk }\end{array}$ & PTBA \\
\hline Astra Agro Lestari, Tbk & AALI \\
\hline PP London Sumatra Indonesia, Tbk & LSIP \\
\hline SMART, Tbk & SMAR \\
\hline Jasa Marga (Persero), Tbk & JSMR \\
\hline Perusahaan Gas Negara, Tbk & PGAS \\
\hline Tower Bersama Infrastructure, Tbk & TBIG \\
\hline Sarana Menara Nusantara, Tbk & TOWR
\end{tabular}

\subsection{Research method}

The research method that used in this study is based on Elton \& Gruber (1977) research result. Elton \& Gruber (1977) research was about the risk reduction and portfolio size. This research was used weekly data period of June 1974 with 3.290 shares sample. The research conclusion stated that the more shares in the portfolio, then the lower risk that can be produce.

\section{Result}

\subsection{Markowitz model}

The first step to develop an optimum portfolio based on Markowitz model is to form a risky asset portfolio. Then, the correlation data and covariance data are necessary to calculate in order to process the data.

Based on the aforementioned table, we can conclude that the highest correlation is ADRO - PTBA (0.616). Those shares are coming from the same industry, which means if ADRO's share price is declining, PTBA's share price is also decline. The negative correlations are coming from ADRO - BYAN, ADRO - SMAR, ADRO - TOWR, BYAN - AALI, 
TABLE 4: Equity analyst buy action report.

\begin{tabular}{|c|c|c|c|}
\hline DATE & COMPANY'S NAME & CODE & REASON FOR BUYING \\
\hline 25-Jul-16 & $\begin{array}{l}\text { Perusahaan Gas Negara, } \\
\text { Tbk }\end{array}$ & PGAS & $\begin{array}{l}\text { With stochastic indicator to form a golden } \\
\text { cross, we expect a upward movement for } \\
\text { PGAS today in the range of } 2880-3070\end{array}$ \\
\hline 2-Aug-16 & Astra Agro Lestari, Tbk & AALI & $\begin{array}{l}\text { With stochastic indicator to form a golden } \\
\text { cross, we expect a technical rebound for } \\
\text { AALI today in the range of } 14400-15300\end{array}$ \\
\hline 3-Aug-16 & Adaro Energy, Tbk & ADRO & $\begin{array}{l}\text { ADRO is expected to continue its } \\
\text { strengthening within the support and } \\
\text { resistance levels of } 1080-1150\end{array}$ \\
\hline 4-Aug-16 & $\begin{array}{l}\text { PP London Sumatra } \\
\text { Indonesia, Tbk }\end{array}$ & LSIP & $\begin{array}{l}\text { LSIP remains in the long term bullish } \\
\text { pattern. With a doji formation indf and } \\
\text { potential gold-en cross on its stochastic } \\
\text { oscillator LSIP is a Speculative Buy. LSIP's } \\
\text { support and re- sistance level ranging } \\
\text { between } 1560-1670 \text { for today. }\end{array}$ \\
\hline 29-Aug-16 & Vale Indonesia, Tbk & INCO & $\begin{array}{l}\text { LSIP remains in the long term bullish } \\
\text { pattern. With a doji formation indf and } \\
\text { potential gold- en cross on its stochastic } \\
\text { oscillator LSIP is a Speculative Buy. LSIP's } \\
\text { support and re-sistance level ranging } \\
\text { between } 1560-1670 \text { for today. }\end{array}$ \\
\hline 1-Sep-16 & $\begin{array}{l}\text { Telekomunikasi Indonesia } \\
\text { (Persero), Tbk }\end{array}$ & TLKM & $\begin{array}{l}\text { TLKM golden cross indicator, and positive } \\
\text { signal from ADX. TLKM Buy with support } \\
\text { resistance at } 4150-4260\end{array}$ \\
\hline 1-Sep-16 & Delta Dunia Makmur, Tbk & DOID & $\begin{array}{l}\text { DOID tweezer bottom candle with golden } \\
\text { cross signal. DOID trading buy with } \\
\text { trading range at } 230-265\end{array}$ \\
\hline
\end{tabular}

and BYAN - TBIG. ADRO - BYAN and BYAN - AALI are coming from different industry, so that they can be complement to each other.

From the aforementioned table, we can see that rate of return of each stock are generally high except for BYAN. However, the risk of each shares are also high. The highest risk is coming from ADRO and INCO. Those two shares are from the same industry, which is mining industry. As we know that mining industry nowadays is quite unstable, tend to decline. So that, although mining industry is able to produce high return (INCO with $73.34 \%$ ), it is also produce highest rate of risk (74.97\%).

The purpose of portfolio selection is to minimize risk with acceptable rate of return, which we called optimum portfolio. To reach that point, we need to determine the suitable proportion for each share. This can be done by solver application on Microsoft Excel. Obtained from solver application with minimal standard deviation as the target, weight who want to be solved is changing cells, the number of weight $=1$, and each 
TABLE 5: Correlations and covariance matrix Markowitz portfolio.

\begin{tabular}{|c|c|c|}
\hline CODE & CORR & COV \\
\hline ADRO-BYAN & $-8.916 \%$ & $-0.015 \%$ \\
\hline ADRO-INCO & $28.783 \%$ & $0.153 \%$ \\
\hline ADRO-ANTM & $26.380 \%$ & $0.122 \%$ \\
\hline ADRO-PTBA & $61.635 \%$ & $0.287 \%$ \\
\hline ADRO-AALI & $28.020 \%$ & $0.128 \%$ \\
\hline ADRO-LSIP & $27.679 \%$ & $0.111 \%$ \\
\hline ADRO-SMAR & $-8.838 \%$ & $-0.035 \%$ \\
\hline ADRO-JSMR & $27.940 \%$ & $0.080 \%$ \\
\hline ADRO-PGAS & $22.217 \%$ & $0.088 \%$ \\
\hline ADRO-TBIG & $20.732 \%$ & $0.064 \%$ \\
\hline ADRO-TOWR & $-7.927 \%$ & $-0.013 \%$ \\
\hline BYAN-INCO & $0.674 \%$ & $0.001 \%$ \\
\hline BYAN-ANTM & $18.151 \%$ & $0.026 \%$ \\
\hline BYAN-PTBA & $-0.342 \%$ & $0.000 \%$ \\
\hline BYAN-AALI & $-7.040 \%$ & $-0.010 \%$ \\
\hline BYAN-LSIP & $0.230 \%$ & $0.000 \%$ \\
\hline BYAN-SMAR & $7.219 \%$ & $0.009 \%$ \\
\hline BYAN-JSMR & $7.102 \%$ & $0.006 \%$ \\
\hline BYAN-PGAS & $5.417 \%$ & $0.007 \%$ \\
\hline BYAN-TBIG & $-2.698 \%$ & $-0.003 \%$ \\
\hline BYAN-TOWR & $20.255 \%$ & $0.011 \%$ \\
\hline INCO-ANTM & $42.123 \%$ & $0.196 \%$ \\
\hline INCO-PTBA & $46.744 \%$ & $0.218 \%$ \\
\hline
\end{tabular}

weight is $0>$ = as constrain. Then, we get weighted average for each stock as stated earlier. Last, we can calculate how much return and minimum risk for this portfolio.

Based on Table 7, we can conclude that proportion of its shares using Markowitz model are divided proportionally for each share. Moreover, we can also conclude that the risk are borne investors has decline if investor diversified their portfolio. it is proven by the risk of each share who had remained in a range up to $70 \%$ before diversified become $5.1 \%$ after diversification. In addition, the rate of portfolio stock return also 
TABLE 6: Risk and return each stocks using portfolio Markowitz Model.

\begin{tabular}{|l|l|l|l|l|}
\hline No. & CODE & E(Ri) & RISK & PROPORTION \\
\hline 1 & ADRO & $37.07 \%$ & $74.68 \%$ & $2.62 \%$ \\
\hline 2 & BYAN & $7.39 \%$ & $23.43 \%$ & $26.63 \%$ \\
\hline 3 & INCO & $73.34 \%$ & $74.97 \%$ & $2.60 \%$ \\
\hline 4 & ANTM & $58.17 \%$ & $65.23 \%$ & $3.43 \%$ \\
\hline 5 & PTBA & $46.27 \%$ & $65.38 \%$ & $3.42 \%$ \\
\hline 6 & AALI & $56.91 \%$ & $64.33 \%$ & $3.53 \%$ \\
\hline 7 & LSIP & $28.66 \%$ & $56.48 \%$ & $4.58 \%$ \\
\hline 8 & SMAR & $62.16 \%$ & $56.38 \%$ & $4.60 \%$ \\
\hline 9 & JSMR & $31.18 \%$ & $40.22 \%$ & $9.04 \%$ \\
\hline 10 & PGAS & $79.42 \%$ & $55.46 \%$ & $4.75 \%$ \\
\hline 11 & TBIG & $40.84 \%$ & $43.10 \%$ & $7.87 \%$ \\
\hline 12 & TOWR & $8.20 \%$ & $23.30 \%$ & $26.92 \%$ \\
\hline Source: Processed by author, 2016. & & \\
\hline
\end{tabular}

TABLE 7: Return and risk portfolio using Markowitz selection portfolio.

\begin{tabular}{|l|l|l|l|l}
\hline NO & CODE & PROPORTION & $\mathbf{R}_{\text {PORTFOLIO }}$ & RISK \\
\hline 1 & ADRORTFLIO \\
\hline 2 & BYAN & $26.63 \%$ & $0.97 \%$ & $0.0 \%$ \\
\hline 3 & INCO & $2.60 \%$ & $1.97 \%$ & $0.4 \%$ \\
\hline 4 & ANTM & $3.43 \%$ & $1.91 \%$ & $0.0 \%$ \\
\hline 5 & PTBA & $3.42 \%$ & $2.00 \%$ & $0.1 \%$ \\
\hline 6 & AALI & $3.53 \%$ & $1.58 \%$ & $0.0 \%$ \\
\hline 7 & LSIP & $4.58 \%$ & $2.01 \%$ & $0.1 \%$ \\
\hline 8 & SMAR & $4.60 \%$ & $1.31 \%$ & $0.1 \%$ \\
\hline 9 & JSMR & $9.04 \%$ & $2.86 \%$ & $0.1 \%$ \\
\hline 10 & PGAS & $4.75 \%$ & $2.82 \%$ & $0.1 \%$ \\
\hline 11 & TBIG & $7.87 \%$ & $3.78 \%$ & $0.1 \%$ \\
\hline 12 & TOWR & $26.92 \%$ & $2.21 \%$ & $0.1 \%$ \\
\hline TOTAL & & $100.00 \%$ & $26.63 \%$ & $5.1 \%$ \\
\hline
\end{tabular}


changes. Investors who diversified having the rate of return $26.63 \%$ from their portfolio. Whereas, investor who not diversified they experience loss due to not get the optimal rate of return.

\subsection{Broker recommendation}

Broker usually offering investor to buy or sell stocks at certain price in certain moment. Some investors are depending on this recommendation because they can't manage their own portfolio daily. This is very common to follow broker's statement, but since broker never state on how much assets we need to add in our portfolio, so for the proportion we still using solver application from Microsoft Excel. Before that, correlation and covariance data are also necessary to show in this method.

From the aforementioned table, we can see that highest correlation is from AALILSIP (0.69). Both of AALI and LSIP are from the same industry, which is Agriculture. It means if AALI's stock price is declining, LSIP's price is also decline. However, based on broker recommendation we can conclude that there are none negative correlations between stocks. It may affect the portfolio later since there is none of those stocks whom able to be complement to each other.

Table 9 shows that return of each stock are generally high except TLKM. The highest return is from PGAS with $79.42 \%$ along with high risk also (55.99\%). The negative return for TLKM is bad signal for our portfolio because it may affect portfolio rate of return. However, ADRO's stock risk in this method is higher than in Markowitz portfolio (75.4\%). Moreover, to obtain the proportion of each stock, we can use solver application with minimal standard deviation as the target, weight who want to be solved is changing cells, the number of weight $=1$, and each weight is $0>=$ as constrain. Then, we get weighted average for each stock as stated earlier. Last, we can calculate how much return and minimum risk for this portfolio.

Based on Table 7, we can conclude that proportion of its shares using Markowitz model are divided proportionally for each share. Moreover, we can also conclude that the risk are borne investors has decline if investor diversified their portfolio. It is proven by the risk of each share that had remained in a range up to $79 \%$ before diversified become $6.29 \%$ after diversification. In addition, the rate of portfolio stock return also changes. Investors who diversified having the rate of return $8.51 \%$ from their portfolio. Whereas, investor who not diversified they experience loss due to not get the optimal rate of return. 
TABLE 8: Correlations and covariance matrix broker recommendation portfolio.

\begin{tabular}{|l|l|l|}
\hline CODE & CORR & COVAR \\
\hline PGAS-AALI & 0.18 & 0.00061 \\
\hline PGAS-ADRO & 0.22 & 0.00088 \\
\hline PGAS-LSIP & 0.24 & 0.00072 \\
\hline PGAS-INCO & 0.29 & 0.00115 \\
\hline PGAS-TLKM & 0.20 & 0.00031 \\
\hline PGAS-DOID & 0.19 & 0.00090 \\
\hline AALI-ADRO & 0.28 & 0.00128 \\
\hline AALI-LSIP & 0.69 & 0.00240 \\
\hline AALI-INCO & 0.47 & 0.00217 \\
\hline AALI-TLKM & 0.02 & 0.00003 \\
\hline AALI-DOID & 0.21 & 0.00114 \\
\hline ADRO-LSIP & 0.28 & 0.00111 \\
\hline ADRO-INCO & 0.29 & 0.00153 \\
\hline ADRO-TLKM & 0.32 & 0.00068 \\
\hline ADRO-DOID & 0.15 & 0.00095 \\
\hline LSIP-INCO & 0.56 & 0.00224 \\
\hline LSIP-TLKM & 0.11 & 0.00018 \\
\hline LSIP-DOID & 0.14 & 0.00067 \\
\hline INCO-TLKM & 0.16 & 0.00033 \\
\hline & 0.00178 \\
\hline ALOID & 0.00049 \\
\hline
\end{tabular}

However, both of Markowitz portfolio and broker recommendation are generating different rate of return and risk. Markowitz portfolio method results higher rate of return than broker recommendation portfolio. This condition might be happen because Markowitz portfolio contains more stocks than broker recommendation. Moreover, in broker recommendation there is negative return from TLKM's stock that may be affect the overall portfolio return. Although through diversification the risk may reduce, but the negative effect is quite strong. The reason why there's only a few stocks in agriculture, mining, and infrastructure industries that recommended by broker giving signal to investors that those industries are not well enough nowadays. So that, 
TABLE 9: Risk and return each stocks using broker recommendation.

\begin{tabular}{|l|l|l|l|l|}
\hline No. & CODE & RETURN & RISK & PROPORTION \\
\hline 1 & PGAS & $79.42 \%$ & $55.99 \%$ & $13 \%$ \\
\hline 2 & AALI & $56.91 \%$ & $64.95 \%$ & $10 \%$ \\
\hline 3 & ADRO & $37.07 \%$ & $75.40 \%$ & $7 \%$ \\
\hline 4 & LSIP & $28.66 \%$ & $57.02 \%$ & $13 \%$ \\
\hline 5 & INCO & $73.34 \%$ & $75.69 \%$ & $7 \%$ \\
\hline 6 & TLKM & $-45.72 \%$ & $30.35 \%$ & $45 \%$ \\
\hline 7 & DOID & $27.27 \%$ & $91.73 \%$ & $5 \%$ \\
\hline
\end{tabular}

TABLE 10: Return and risk portfolio using broker recommendation.

\begin{tabular}{|l|l|}
\hline No. & CODE \\
\hline 1 & PGAS \\
\hline 2 & AALI \\
\hline 3 & ADRO \\
\hline 4 & LSIP \\
\hline 5 & INCO \\
\hline 6 & TLKM \\
\hline 7 & DOID \\
\hline TOTAL & \\
\hline
\end{tabular}

\begin{tabular}{|c|}
\hline PROPORTION \\
\hline $13 \%$ \\
\hline $10 \%$ \\
\hline $7 \%$ \\
\hline $13 \%$ \\
\hline $7 \%$ \\
\hline $5 \%$ \\
\hline $100 \%$ \\
\hline
\end{tabular}

\begin{tabular}{|l|}
\hline R PORTOFOLIO \\
\hline $10.47 \%$ \\
\hline $5.58 \%$ \\
\hline $2.70 \%$ \\
\hline $3.64 \%$ \\
\hline $5.29 \%$ \\
\hline$-20.52 \%$ \\
\hline $1.34 \%$ \\
\hline $8.51 \%$ \\
\hline
\end{tabular}

\begin{tabular}{|c|}
\hline RISK PORTOFOLIO \\
\hline $0.55 \%$ \\
\hline $0.41 \%$ \\
\hline $0.30 \%$ \\
\hline $0.53 \%$ \\
\hline $0.30 \%$ \\
\hline $1.86 \%$ \\
\hline $0.20 \%$ \\
\hline $6.29 \%$ \\
\hline
\end{tabular}

rational investor should look up to other industries such as miscellaneous industry or consumer goods, which are, have negative correlation.

\section{Conclusion}

Diversification portfolio was advice most qualified to invest in the stock market. Investors who diversified its shares for the purpose to reduce the risk because loss at one shares can be covered with a profit on the other share. The performance of a portfolio be very much determined by return expectations and risks with him. Portfolio risk is strongly influenced by risk each stock, the percentage/weight each share and also the correlation across shares in the formation of portfolio. Method selection in doing valuation portfolio is also affect the rate of return of a portfolio. Method selection in doing valuation portfolio is also affect the rate of return of a portfolio. In this article, it can be seen that valuation portfolio in a Markowitz model is greater than broker 
recommendation. This is because in Markowitz model there is 12 shares that put in their portfolio while in broker recommendation only use 7 shares. Hence, it can be concluded that the more shares in investor's portfolio will be able to reduce the risk that had to borne and yielding bigger the rate of return also.

\section{References}

[1] Bayumashudi, A. (2006). Analisis Pembentukan Portofolio Optimum Menggunakan Model Pemilihan Portofolio Markowitz Terhadap Saham-Saham LQ-45 di Bursa Efek Jakarta. Jakarta: Universitas Indonesia.

[2] Bodie, Z., Kane, A., \& Marcus, A. (2011). Investments and Portofolio Management (gth Ed.). New York: McGraw-Hill.

[3] Dahlan, S., Topowijono, Z.A, Zahroh. (2013). Penggunaan Single Index Model Dalam Analisis Untuk Meminimumkan Risiko Bagi Investor Di Pasar Modal (Studi Pada Saham Perusahaan yang Tercatat Dalam Indeks LQ 45 di Bursa Efek Indonesia Periode 2010-2012). Jurnal Administrasi Bisnis, Vol 6 No. 2.

[4] Eko, Umanto. (2008). Analisis dan Penilaian Kinerja Portofolio Optimal SahamSaham LQ- 45. Jurnal Ilmu Administrasi dan Organisasi, Vol 15 No. 3: 178-187.

[5] Jones, C. P., Utama, B. Frensidy, I.A. Ekaputra, R. Untung. (2009). Investment Analysis and Management, an Indonesian Adaptation. John Willey \& Sons dan Salemba Empat. Jogiyanto, H. M. 2008. Teori Portofolio dan Analisis Investasi. Edisi 2008. Yogyakarta: BPFE.

[6] Laporan Nusantara Februari 2014 : Perkembangan Terkini, Prospek, dan Tantangan Kedepannya, kajian Bank Indonesia.

[7] Nuraida, D. (2004). Analisis Variabel yang Mempengaruhi Pemilihan Saham Oleh Manajer Investasi Untuk Membentuk Portofolio yang Optimal di BEJ Periode 20002002. Depok: Universitas Indonesia.

[8] Research \& Product Development Division. (2013). IDX Statistic 2008. Working Paper, Indonesia.

[9] Saragih, Ferdinand D., Nugroho. (2008). Keuangan Internasional. Depok: Departemen Ilmu Administrasi Fakultas Ilmu Sosial dan Ilmu Politik Universitas Indonesia. Warsini, S. (2009). Manajemen Investasi. Jakarta: Penerbit Semesta Media. 